\title{
A laboratory study on feeding plasticity of the shredder Sericostoma vittatum Rambur (Sericostomatidae)
}

\author{
Emerson M. Carvalho • Manuel A. S. Graça
}

Received: 29 November 2005/Revised: 9 August 2006/ Accepted: 12 August 2006/ Published online: 6 October 2006 (C) Springer Science+Business Media B.V. 2006

\begin{abstract}
Since litter input and availability of leaves in many streams is highly seasonal in Portugal, we investigated whether Sericostoma vittatum, a typical shredder, was able to grow using alternative food sources. To test this hypothesis we fed $S$. vittatum with Alnus glutinosa (alder, CPOM, coarse particulate organic matter), leaf powder from A. glutinosa and Acacia dealbata and FPOM (fine particulate organic matter) from a 5th and a $>6$ th order river, the macrophyte Myriophyllum aquaticum and biofilm. Growth in $S$. vittatum was significantly influenced by the food item given (ANOVA, $P=0.0082$ ). The food item promoting the highest growth was $A$. glutinosa, in the form of FPOM $\left(6.48 \%\right.$ day $\left.^{-1}\right)$ and CPOM (4.24\% day $\left.^{-1}\right)$; all other forms of FPOM and biofilm provided relatively low growth rates $\left(0.77-1.77 \%\right.$ day $\left.^{-1}\right)$. The macrophyte M. aquaticum was also used as food source by $S$. vittatum and promoted intermediate growth
\end{abstract}

Handling editor: K. Martens

E. M. Carvalho $(\bowtie)$

Departamento de Zoologia, CP 510,

UNESP_Universidade Estadual Paulista, 18618-000

Botucatu, SP, Brasil

e-mail: ecarvalho@ibb.unesp.br

M. A. S. Graça

Departamento de Zoologia, Universidade de

Coimbra, 3004-517 Coimbra, Portugal $\left(1.96 \%\right.$ day $\left.^{-1}\right)$. Neither nitrogen, phosphorus nor caloric content was correlated with growth. However, since higher growth was achieved with alder, in the form of CPOM and FPOM, we concluded that the chemical content of food was more important for $S$. vittatum than the physical form of such food. This may partially explain why shredders are able to survive when leaves are scarce in streams.

Keywords Shredder ' Sericostomatidae · Laboratory study · Growth rates · Food quality

\section{Introduction}

Many headwater streams are strongly influenced by riparian vegetation, which reduces autotrophic production by shading and supplies energy in the form of leaves (Vannote et al., 1980; Abelho, 2001). The decomposition of litter in streams is a biological process involving both microorganisms and invertebrate consumers (Boulton \& Boon, 1991; Abelho, 2001; Graça, 2001) resulting in the incorporation of energy from the litter into secondary production and in the release of large amounts of fine particulate organic matter (FPOM-Gessner et al., 1999). The production of FPOM can be ecologically important for populations of collector living further downstream (Graça, 2001). 
Given the natural variability of rain and litter input in streams, which dictate retention and transport of organic matter (e.g. Pardo \& Ávarez, 2006), it is plausible that many stream invertebrates exhibit some variation in their diet. This has been demonstrated specifically in shredders. For instance, Friberg \& Jacobsen (1994) showed that conditioned alder leaves and fresh filamentous green algae were equally palatable for two shredder species. Mihuc \& Mihuc (1995) also showed that four shredder species exhibited similarly high growth rates when fed periphyton and coarse particulate organic matter (CPOM) resources. Franken et al. (2005) showed that biofilm on leaf surfaces can be an important component of the nutritional for two shredder species. Feeding plasticity or generalist diet may allow invertebrates to cope with the variability of food sources in streams.

Some typical shredders in streams of Central Portugal include the caddisflies Sericostoma vittatum Rambur (Feio \& Graça, 2000; Graça et al., 2001; González \& Graça, 2003), Lepidostoma hirtum Spence (Azevedo-Pereira et al., 2006) and Tipula spp. (Canhoto \& Graça, 1999). In the São João stream, central Portugal, the caddisflies $S$. vittatum and $L$. hirtum were calculated to consume between 2.3 and 8.6 times the mean annual CPOM standing stock in the stream (González \& Graça, 2003; AzevedoPereira et al., 2006). Those high values and the observed variability of organic matter in the stream bed throughout the year (González \& Graça, 2003) suggest that the detritivore guild, at times, may have limited food in the S. João stream and that they may be capable of modifying their behavior and diet according to food availability. Certainly the same situation occurs in many other systems (Boulton \& Boon, 1991).

In the present study, we hypothesize that shredders are able to maintain viable population in streams because of their capability of feeding and growing on alternative food sources. As a test organism we used $S$. vittatum Rambur. The study was carried out in the laboratory and, besides alder leaves, we used as alternative food sources FPOM, a macrophyte, and biofilm.

\section{Materials and methods}

Specimens of $S$. vittatum were collected in May 2005 at the S. João stream, Lousã, Portugal $\left(40^{\circ} 06^{\prime} \mathrm{N}, 8^{\circ} 14^{\prime} \mathrm{W}\right)$. This species was selected because it is numerically abundant and information on their trophic ecology in the studied stream was already available (e.g. Feio \& Graça, 2000; Graça et al., 2001; González \& Graça, 2003). The riparian trees along the stream include Castanea sativa Miller, Quercus spp., Pinus pinaster Aiton, Acacia dealbata Link and Alnus glutinosa (L.) Gaertner. The collected specimens were acclimatized in the laboratory for 5 days prior to the experiments.

Seven food items were used in the experiments. CPOM was provided in the form of pieces of leaves of $A$. glutinosa. Leaf powder came from $A$. glutinosa and Acacia dealbata, which were obtained with a homogenizer (Poly Tron ${ }^{\circledR}$ PT 2100). The material was sieved and only the fraction passing through a sieve of $1.00 \mathrm{~mm}$ and retrieved by a sieve of $0.18 \mathrm{~mm}$ was used. All the above leaves were conditioned for 2 weeks in nylon bags $(0.5 \mathrm{~mm}$ mesh size) submerged in the stream. FPOM from the S. João and Ceira streams (tributaries of the Mondego River) were collected directly from the stream-bed and sieved as described above. As a macrophyte food source we used Myriophyllum aquaticum (Vell.) Verdc. This species is common in the lower sections of the Mondego River basin and was available during the experimental period. Biofilm was obtained by exposing stream cobbles $(\approx 40 \mathrm{~mm}$ diameter $)$ in a shallow in a tank at the University Botany Garden for 4 weeks. By that time, a visible apparently uniform algal grow was evident over all substrates.

The ash free dry mass (AFDM) of each food item was determined as the difference between dry mass (oven dried at $60^{\circ} \mathrm{C}, 2$ days) and the ash mass $\left(550^{\circ} \mathrm{C}, 4 \mathrm{~h}\right)$. Total nitrogen and phosphorous content in all food items were determined according to Flindt \& Lillebo (2005). Chlorophyll $a$ content was determined by spectrophotometry (Eaton et al., 1995). Three replicates of each food item were used for the above analyses and expressed per unit of AFDM. The energy 
content of each food item was determined in five replicates with a PARR 1425 pump calorimeter. Results were expressed in terms of $\mathrm{kJ} \mathrm{g}^{-1}$ AFDM.

A total of 280 specimens of $S$. vittatum with sizes ranging from 3.4 to $6.8 \mathrm{mg}$ were used in the experiments. Specimens were allocated individually into plastic cups containing $200 \mathrm{ml}$ of filtered stream water (GF/C Whatman) and the bottom covered by stream sand (ignited for $4 \mathrm{~h}$ at $550^{\circ} \mathrm{C}$ ). Aeration was provided with pipette plastic tips connected to an air pump. The invertebrates were randomly assigned to food categories, being 40 individuals for each food items (seven treatments). Food was provided "ad libitum"-leaves: several pieces of approximately $2 \times 2 \mathrm{~cm}$ each; FPOM: two spoons of material; macrophyte: 2 leaves; biofilm: 3 cobbles. The amount of available food was daily checked and replenish if necessary. All food items and $50 \%$ of the water were renewed weekly. The individuals who pupated were not replaced.

There were no statistical differences in the initial mass of individuals in the seven treatments (ANOVA $P>0.86$ ). The experiments were carried out for 14 days under $15 \pm 1^{\circ} \mathrm{C}$ and a photoperiod of 12:12 h (light:dark). The temperature $15^{\circ} \mathrm{C}$ was previously shown to be near the optimum for growth in this species (González \& Graça, 2003).

The initial and final sizes (in $\mathrm{mg}$ ) of each individual were estimated from the diameter $(\mathrm{mm})$ of the anterior opening of the caddis case according to Canhoto (1994; $r^{2}=90.8 \%$; $n=27)$. Daily growth rates (DGR) were calculated as the difference between the final and initial dry mass, divided by the elapsed time in days (14 days). The percentage of daily growth was computed by dividing the DGR by the initial mass, multiplied by 100 (Feio \& Graça, 2000).

Comparison of growth rates and physicochemical properties of food among treatments were done by one-way ANOVA performed on arcsine-transformed data (Zar, 1999), followed by comparisons with the Tukey HSD test for unequal $\mathrm{N}$ (replicates). The relationship between growth and food properties was tested by the Spearman Rank Correlation.

\section{Results}

The 7 food items differed in all physical and chemical parameters (ANOVA $P<0.001$ ). Nitrogen content from leaves or leaf powder was similar to natural FPOM from S. João stream, but lower than the natural FPOM from the larger Ceira River (Table 1). The percentage of organic material in the natural FPOM was very low and different between rivers: approximately $18 \%$ in the S. João and 4\% in the Ceira (Table 1). FPOM from streams had some algae, although much lower than the biofilm recovered from stones (Table 1). The mean caloric content was highest in leaves either entire or reduced to FPOM (Table 1). The two natural FPOM differed significantly in terms of calorie content. It was lower in the Ceira than in the S. João stream (Table 1).

Survival of $S$. vittatum larvae during the experiment ( 2 weeks) was $100 \%$. However, some animals pupated and therefore growth of these specimens was not computed. The highest pupation occurred in specimens fed FPOM A. glutinosa $(17.5 \%)$ followed by FPOM S. João (15\%). The size of specimens entering pupation in the set fed with $A$. glutinosa (in the form of FPOM and CPOM) was about double that for the other food items (Fig. 1). No pupation occurred in larvae feeding on macrophyte and biofilm.

Growth rate of $S$. vittatum was significantly influenced by the food item (ANOVA, $P=0.0082$ ). The food item promoting the highest growth was $A$. glutinosa, in the form of FPOM $\left(6.48 \% \mathrm{day}^{-1}\right)$ and CPOM (4.24\% day ${ }^{-1}$, Fig. 2); all other forms of FPOM and biofilm provided relatively low growth rates $\left(0.77-1.77 \%\right.$ day $^{-1}$, Fig. 2). Growth on FPOM from A. dealbata promoted 4 times lower growth rate than FPOM from A. glutinosa. Neither nitrogen, phosphorus nor energy content was significantly correlated with grow (Fig. 3).

\section{Discussion}

Growth values reported in the present work for sets of shredders feeding on alder $\left(4.24 \%\right.$ day $\left.^{-1}\right)$ were in the upper range of those reported by Graça et al. (2001; 2.9\% day ${ }^{-1}$, for sets of 
Table 1 Properties of 7 food items offered to the shredder $S$. vittatum: values are means \pm SE of nitrogen (N), phosphorus $(\mathrm{P})$, organic material $(\mathrm{OM})$, chlorophyll $a\left(\mathrm{Cla}, \mathrm{mg} \mathrm{g}^{-1}\right)$, and energy contents $\left(\mathrm{EC}, \mathrm{kJ} \mathrm{g}^{-1}\right)$

\begin{tabular}{|c|c|c|c|c|c|c|c|c|c|c|}
\hline Food items & $\mathrm{N} \%$ & $\mathrm{Tt}$ & $\mathrm{P} \%$ & Q & OM \% & $\mathrm{Tt}$ & Cla $\mathrm{mg} \mathrm{g}^{-1}$ & $\mathrm{Tt}$ & $\mathrm{EC} \mathrm{kJ} \mathrm{g}^{-1}$ & $\mathrm{Tt}$ \\
\hline CPOM Alnus & $3.8 \pm 0.1$ & B & $0.05 \pm 0.005$ & $\mathrm{AB}$ & $84.2 \pm 0.12$ & B & not applicable & & $438 \pm 6$ & A \\
\hline FPOM Alnus & $3.3 \pm 0.1$ & $\mathrm{~B}$ & $0.04 \pm 0.003$ & $\mathrm{AB}$ & $85.1 \pm 0.05$ & B & not applicable & & $348 \pm 32$ & A \\
\hline FPOM Acacia & $3.5 \pm 0.2$ & B & $0.02 \pm 0.001$ & B & $93.7 \pm 0.13$ & A & not applicable & & $387 \pm 11$ & A \\
\hline FPOM S. João & $3.9 \pm 0.1$ & B & $0.12 \pm 0.01$ & A & $18.8 \pm 0.38$ & $\mathrm{E}$ & $2.20 \pm 0.02$ & B & $244 \pm 106$ & $\mathrm{AB}$ \\
\hline FPOM Ceira & $10.7 \pm 1.4$ & A & $0.10 \pm 0.05$ & $\mathrm{AB}$ & $4.3 \pm 0.1$ & $\mathrm{~F}$ & $2.50 \pm 0.2$ & $\mathrm{~B}$ & $2.62 \pm 0.24$ & $\mathrm{C}$ \\
\hline Macrophyte & $3.4 \pm 0.2$ & $\mathrm{~B}$ & $0.10 \pm 0.004$ & $\mathrm{AB}$ & $87.5 \pm 0.11$ & $\mathrm{C}$ & not applicable & & $287 \pm 2.4$ & $\mathrm{AB}$ \\
\hline Biofilm & $2.5 \pm 0.2$ & B & $0.03 \pm 0.002$ & $\mathrm{AB}$ & $66.2 \pm 0.55$ & $\mathrm{D}$ & $38.00 \pm 0.02$ & A & $60 \pm 0.7$ & $\mathrm{BC}$ \\
\hline
\end{tabular}

Values expressed per unit of AFDM. Letters indicate homogeneous groups obtained with the Tukey HSD test (Tt)

specimens with initial size of $1.7 \mathrm{mg}$ ). The aim of the experiments here reported was to determine whether typical shredders can present growth using alternative food resources. The main result was that $A$. glutinosa, both in the form of whole leaves and in reduced FPOM form, promoted similar growth for $S$. vittatum. Therefore, the chemical composition of these leaves, rather than their physical form, was the important factor for growth in our laboratory experiments. This is consistent with the fact that all other forms of FPOM provided relatively low growth. FPOM from A. dealbata and A. glutinosa, were physically similar to each other, but the latter food item promoted 4 times more growth. The high value of A. glutinosa leaves as a food resource was also reported for other shredders (e.g. Friberg \& Jacobsen, 1994, 1999, Jacobsen \& Friberg, 1995, Graça et al., 2001, González \& Graça, 2003).

The macrophyte $M$. aquaticum was also used as food source by S. vittatum and promoted some growth. However, the value was $64 \%$ lower, compared with leaves of $A$. glutinosa. Friberg \& Jacobsen (1994) also showed that the second most consumed food item was also fresh macrophyte, presenting values ranging from $73 \%$ to $37 \%$ when compared with leaves of $A$. glutinosa; however, these authors did not measure growth.

When specimens were fed biofilm, their growth was $58 \%$ lower than that obtained with leaves of A. glutinosa. The capability of shredders for growth when fed with periphyton was also demonstrated with five shredder species by Mihuc \& Mihuc (1995). Franken et al. (2005) also showed that biofilm on leaf surfaces had a significant positive effect on the growth of two shredder species. In acidic streams where grazers were absent, Ledger \& Hildrew (2005) found that typical shredders such as Leuctridae were important grazers, regulating benthic algae. It seems therefore that some shredders may, in some instances, use benthic algae as energy source.

The FPOM collected directly from the stream was high in nutrient content. FPOM is supposedly constituted by very refractive particles such as pieces of leaves not consumed by fungi or invertebrates, and very high quality resources such as fecal pellets, algae and bacteria. The quality of
Fig. 1 Biomass of $S$. vittatum (mg DM; mean \pm SE), pupating during the experiment and their food source

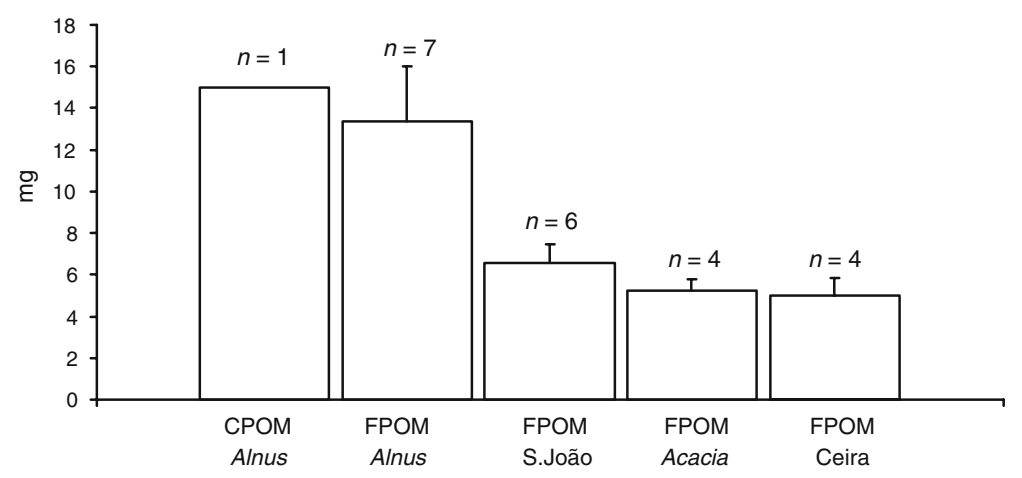




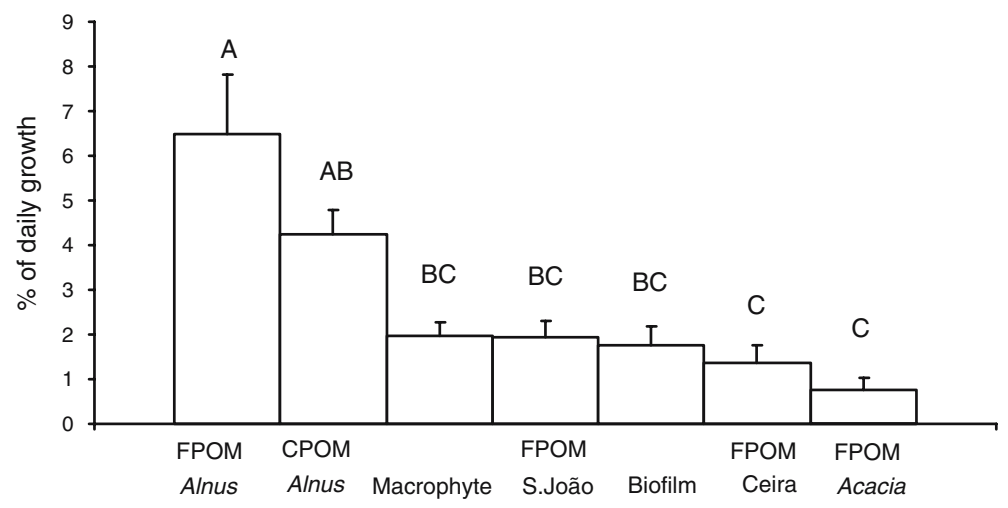

Fig. 2 Percentage of daily growth (mean \pm SE) of $S$. vitattum fed with 7 food items during 2 weeks (one-way ANOVA: $P=0.0082$ ). Letters above bars indicate homogeneous groups obtained with Tukey HSD test

FPOM is therefore expected to vary seasonally and across streams and therefore its capability to promote growth is variable. In terms of nutrients, Graça et al. (2001) and Friberg \& Jacobsen (1999) reported in A. glutinosa nitrogen values of $3.5 \%$ and $3.1 \%$, respectively, and phosphorus levels of $0.09 \%$ in both, which is comparable to the values found in the present study, 3.8\% and $0.05 \%$, respectively. The biofilm we measured on the incubated stones was $3.8 \mathrm{mg} \mathrm{m}^{-2}$ of chlorophyll $a$, which is similar to the $2.5 \mathrm{mg} \mathrm{m}^{-2}$ reported by Fisher Wold \& Hershey (1999). We calculated biomass at $10 \mathrm{~g} \mathrm{~m}^{-2}$ AFDM, which was higher than the $4 \mathrm{~g} \mathrm{~m}^{-2}$ cited by the same authors. However, those differences are expected given the large differences in water chemistry, temperature and other conditions in rivers.

None of the factors-nitrogen, phosphorus or caloric content-was correlated with growth, as also reported by Friberg \& Jacobsen (1999) for nitrogen content. This lack of correlation suggests that other food properties, such as the presence of plant chemical compounds and chemical defenses, micro-nutrients or others are important for shredder consumers. It is relevant to note that leaves of $A$. dealbata and $A$. glutinosa in the form of FPOM promoted the minimum and maximum animal growth rates, respectively, though they presented relatively equal energy content values. In many cases it is difficult, if not impossible, to distinguish between selective feeding and physical or chemical restriction that prevent the intake of all apparently available food material (Cummins, 1973). Since the texture of FPOM samples provided to $S$. vittatum was similar, it is clear the chemical composition of the food is important for shredders.

Pupation may also be an indicator of food quality. Diverse life-history patterns have evolved to enable species to exploit foods that are seasonably available, to time emergence for appropriate environmental conditions, to evade unfavorable physical conditions, and to minimize repressive biotic interaction (Merritt \& Cummins, 1996). Whereas individuals fed on alder entered into pupation at a large size, sets of animals feeding on other food sources diverted energy from growth into pupation. Smaller pupae may result in smaller adults and presumably, smallersized reproductive output (Begon et al., 1990).

In a broad ecological context, if the results shown here can be generalized for other shredder species, then the Functional Feeding Groups should be taken from a very flexible perspective, in which shredders feed on CPOM when available, but are capable of surviving, growing and reproducing using other resources. According with Mihuc, (1997) shredders can function as a generalist or specialist at any point in time. This flexible feeding strategy may explain densities of shredders higher than the expected from the available resources (e.g. González \& Graça, 2003; Azevedo-Pereira et al., 2006; Graça \& Canhoto, 2006). In an ecological context, a generalist strategy makes sense if consumers inhabit environments with high variability of food resources. That is the case when litter input is seasonal in temperate stream systems where hydrological events may wash away leaves (Abelho, 2001) and 

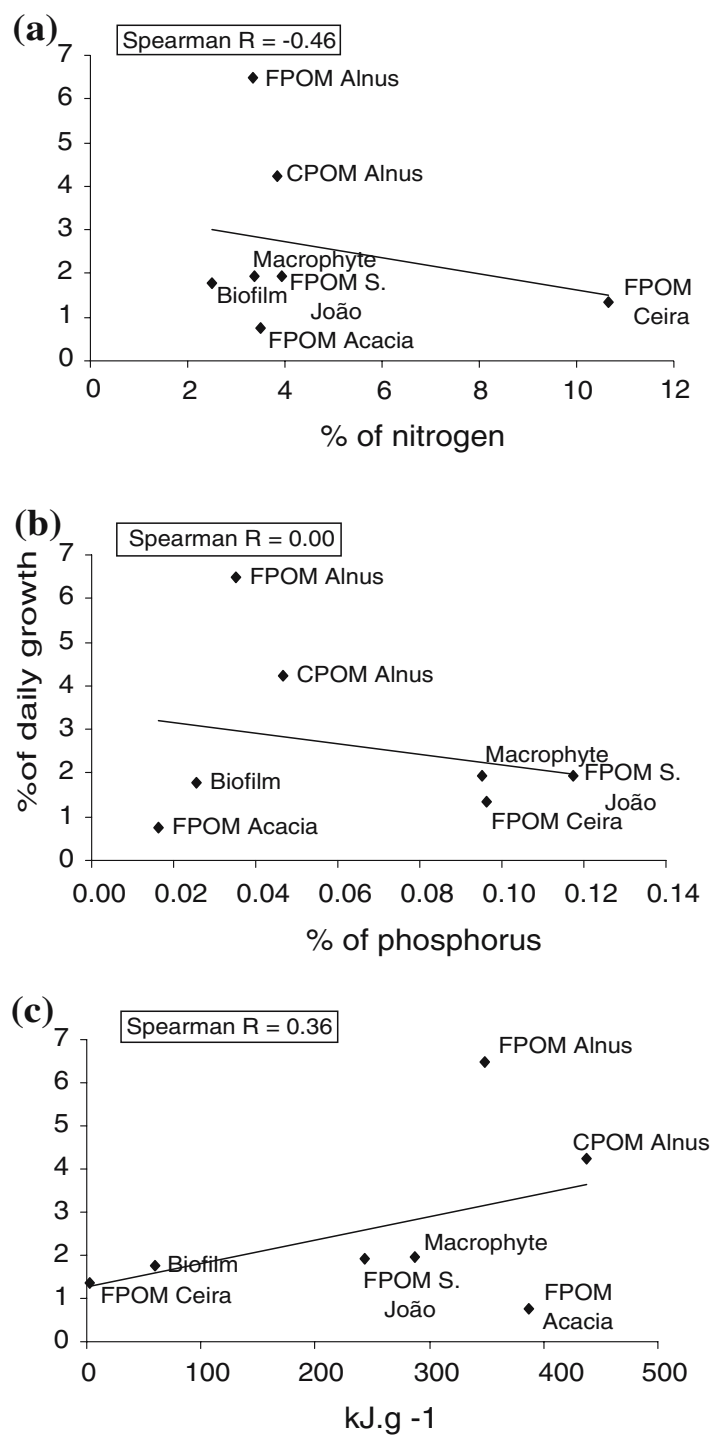

Fig. 3 The relationship between percentage of daily growth of $S$. vitattum and (a) nitrogen, (b) phosphorus and (c) energy $\left(\mathrm{kJ} \mathrm{g}^{-1}\right)$ of the 7 food items (Spearman Rank Correlation, $P>0.05)$

where spring and summer litter input is minimal. Therefore, according with Mihuc (1997), the use of Functional Feeding Groups to describe resource assimilation at the population or community level may be inappropriate, once that generalist resource partitioning seems to be predominance among lotic macroinvertebrates.

Acknowledgements This research was supported by CAPES Research Grant (BEX 1732/04-8) and Portuguese
Science Foundation, grant POCTI/BIA-BDE/58297/2004.

Nuno Coimbra assisted in the field and laboratory

\section{References}

Abelho, M., 2001. From litterfall to breakdown in streams: a Review. The Scientific World 1: 656-680.

Azevedo-Pereira, H. V. S., M. A. S. Graça \& J. M. González, 2006. Life history of Lepidostoma hirtum in an Iberian stream and its role on organic matter processing. Hydrobiologia 559: 183-192.

Begon, M., J. L. Harper \& C.R. Townsend, 1990. Ecology, Individuals, Populations and Communities, 2nd edn. Blackwell Scientific Publications.

Boulton, A. J. \& P. I. Boon, 1991. A review of methodology used to measure leaf litter decomposition in lotic environments: time to turn over an old leaf?. Australian Journal of Marine and Freshwater Research 42: 1-43.

Canhoto, C., 1994. A decomposição e utilização das folhas de Eucalyptus globulus como fonte alimentar por detritivoros aquáticos. Master Thesis. Universidade de Coimbra, Coimbra, 94 pp.

Canhoto, C. \& M. A. S. Graça, 1999. Leaf barriers to fungal colonization and shredders (Tipula lateralis) consumption of decomposing Eucalyptus globulus. Microbial Ecology 37: 163-172.

Cummins, K. W., 1973. Trophic relations of aquatic insects. Annual Review of Entomology 18: 183-206.

Eaton, A. D., L. S. Clesceri \& A. E. Greenberg, 1995. Standard Methods for the Examination of Water and Wastewater. American Public Health Association, Washington.

Feio, M. J. \& M. A. S. Graça, 2000. Food consumption by the larvae of Sericostoma vittatum (Trichoptera), an endemic species from the Iberian Peninsula. Hydrobiologia 439: 7-11.

Fisher Wold, A. K. \& A. E. Hershey, 1999. Effects of salmon carcass decomposition on biofilm growth and wood decomposition. Canadian Journal of Fisheries and Aquatic Sciences 56: 767-773.

Flindt, M. R. \& A. I. Lillebø, 2005. Determination of total nitrogen and phosphorus in leaf litter. In Graça, M. A. S., F. Bärlocher, \& M. O. Gessner (eds), Methods to Study Litter Decomposition. A practical guide. Spring Publ., Netherlands, 53-59.

Franken, R. J. M., B. Waluto, E. T. H. M. Peeters, J. J. P. Gardeniers, J. A. J. Beijer \& M. Scheffer, 2005. Growth of shredders on leaf litter biofilm: the effect of light intensity. Freshwater Biology 50: 459-466.

Friberg, N. \& D. Jacobsen, 1994. Feeding plasticity of two detritivore-shredders. Freshwater Biology 32: 133142.

Friberg, N. \& D. Jacobsen, 1999. Variation in growth of the detritivore-shredder Sericostoma personatum (Trichoptera). Freshwater Biology 42: 625-635.

Gessner, M. O., E. Chauvet \& M. Dobson, 1999. A perspective on leaf litter breakdown in stream. Oikos 85: 377-384. 
González, J. M. \& M. A. S. Graça, 2003. Conversion of leaf litter to secondary production by a shredding caddisfly. Freshwater Biology 48: 1578-1592.

Graça, M. A. S., 2001. The role of invertebrates on leaf litter decomposition in stream: a Review. International Review of Hydrobiologia 86: 383-393.

Graça, M. A. S. \& C. Canhoto, 2006. Leaf litter processing in low order streams. Limnetica 25: 1-10.

Graça, M. A. S., C. Gressa, M. O. Gessner, M. J. Feio, K. A. Callies \& C. Barrios, 2001. Food quality, feeding preferences, survival and growth of shredders from temperate and tropical streams. Freshwater Biology 46: 947-957.

Jacobsen, D. \& N. Friberg, 1995. Food preference of the trichopteran larva Anabolia nervosa from two streams with different food availability. Hydrobiologia 308: 139-144.

Ledger, M. E. \& A. G. Hildrew, 2005. The ecology of acidification and recovery: changes in herbivore-algal food web linkages across a stream $\mathrm{pH}$ gradient. Environmental Pollution 133: 1003-1118.
Merritt, R. W. \& K. W. Cummins, 1996. An Introduction to the Aquatic Insects of North America. Kendall/ Hunt, Dubuque, 862 p.

Mihuc, T. B., 1997. The functional trophic role of lotic primary consumers: generalist versus specialist strategies. Freshwater Biology 37: 455-462.

Mihuc, T. B. \& J. R. Mihuc, 1995. Trophic ecology of five shredders in a Rocky Mountain stream. Journal of Freshwater Ecology 10: 209-216.

Pardo, I. \& M. Ávarez, 2006. Comparison of resources and consumer dynamics in Atlantic and Mediterranean streams. Limnetica 25: 271-286.

Vannote, R. L., G. W. Minshall, K. W. Cummins, J. R. Sedell \& C. E. Cushing, 1980. The river continuum concept. Canadian Journal of Fisheries and Aquatic Sciences 37: 130-137.

Zar, J. H., 1999. Biostatistical Analysis. Prentice Hall, New Jersey, 663 pp. 